\title{
Study of the flash drying of the residue from soymilk processing - "okara"
}

\author{
Estudo da secagem em flash dryer do resíduo - "okara" - resultante do processamento do leite de soja
}

\author{
Regina Kitagawa GRIZOTTO ${ }^{1 *}$, José Maurício de AGUIRRE ${ }^{1}$
}

\begin{abstract}
The objective of this research project was to study the drying of soymilkresiduein a pneumatic flash dryer, using Response Surface Methodology(RSM), and to evaluate the quality of the dried residue. Soymilk residue, also known as okara, was provided by a Brazilian soymilk factory. RSM showed that for a 120 second drying cycle, the lower the residue moisture contents $(\mathrm{y})$ obtained, the higher the recirculation rates $\left(\mathrm{x}_{1}\right)$, regardless of the air drying temperature $\left(\mathrm{x}_{2}\right)$, and it could be expressed by the equation $y=7.072-7.92 x_{1}$, with $R^{2}=92,92 \%$. It is possible to obtain okara with $10 \%$ of moisture $(\mathrm{dwb})$ under the condition $\mathrm{x}_{1}=1.25$, equivalent to $\mathrm{RR}=61 \%$, with air drying temperatures ranging from $252{ }^{\circ} \mathrm{C}$ to $308{ }^{\circ} \mathrm{C}$. The dried okara obtained through Central Compound Rotational Design (CCRD) presented a centesimal composition similar to the okara dried in a tray dryer, known as the original okara. There were significant variations $(\mathrm{p} \leq 0.05)$ in the Emulsifying Capacity (EC), Emulsion Stability (ES) and Protein Solubility (PS) between the dehydrated residues obtained. It was concluded that the flash drying of okara is technically feasible and that the physicochemical composition of the residue was not altered; on the contrary, the process promoted a positive effect on the technological functional properties.

Keywords: soymilk residue; drying; pneumatic dryer; technological functional properties.
\end{abstract}

\section{Resumo}

O objetivo deste projeto de pesquisa foi estudar a secagem do resíduo do leite de soja em secador pneumático flash dryer utilizando a Metodologia de Superfície de Respostas (MSR) e avaliar a qualidade do resíduo desidratado. O resíduo do leite de soja, também conhecido como okara, foi fornecido por indústria brasileira. A MSR demonstrou que, para um ciclo de 120 segundos de secagem, menores teores de umidade (y) são obtidos quando maior a taxa de recirculação $\left(\mathrm{x}_{1}\right)$, independente da temperatura do ar de secagem $\left(\mathrm{x}_{2}\right)$, e pode ser expressa pela equação: $y=7,072-7,92 x_{1} \operatorname{com} R^{2}=92,92 \%$. É possível obter okara com $10 \%$ de umidade (b.u.) na condição $\mathrm{x}_{1}=1,25$ equivalente a $\mathrm{RT}=61 \%$ e ar de secagem na temperatura de $252^{\circ} \mathrm{C}$ a $308^{\circ} \mathrm{C}$. O okara obtido pelo Delineamento Central Composto Rotacional (DCCR) apresentou composição centesimal semelhante ao resíduo desidratado em secador de bandejas, denominado resíduo original. Houve variação significativa ( $\mathrm{p} \leq$ 0,05) na Capacidade de Emulsificação (CE), Estabilidade da Emulsão (EE) e Solubilidade da Proteína (SP) entre os okaras desidratados. Podemos concluir que a secagem do okara em flash dryer é viável tecnicamente e não alterou a composição físico-química do okara, ao contrário, promoveu efeito positivo nas propriedades funcionais tecnológicas.

Palavras-chave: resíduo de leite de soja; secagem; secador pneumático; propriedades funcionais tecnológicas.

\section{Introduction}

There is an urgent need to develop technology in order to use the residue resulting from soymilk processing, also known as okara, due to the large volume produced, which, according to Costa and Mori (1978) and Grizotto et al. (2006), is about 2 to 3 tons per ton of soybean processed. The okara produced contains 85 g. $100 \mathrm{~g}^{-1}$ moisture and a high protein content (40 g.100 g ${ }^{-1}$ on a dry weight basis) (GRIZOTTO et al., 2006) and deteriorates rapidly if no conservation method is applied (AGUIRRE et al., 1981).

The drying technique is the most viable means of conserving this residue, allowing for considerable economy in handling, storage and transportation costs (AGUIRRE et al., 1978). Travaglini et al. (1980b) studied the drying of okara in a tray dryer with forced air circulation at $65^{\circ} \mathrm{C}$, and observed that the quality of the protein was maintained, with about $96 \%$ destruction of the trypsin inhibitor factor. According to these authors, the inconvenience of this method was the low productivity, since it is a discontinuous process requiring long drying periods. Aguirre et al. (1981) reported that the drying of okara in a drum dryer resulted in a better product than that dried in a tray dryer, as far as the protein quality was concerned, showing a Protein Dispersibility Index (PDI) between 8 and $20 \%$, indicating that the drying procedure did not depreciate the quality of protein. Nevertheless, the disadvantage of this method was the elevated cost of the equipment.

When drying okara, one of the most important aspects to be considered is the preservation of the protein quality, which can be affected by the drying conditions. The okara protein is of extremely high quality and the amino acid profile, determined by the Protein Efficiency Ratio (PER), is slightly superior to that of the soymilk itself, according to reports by Hackler et al. (1963) and Travaglini et al. (1980a,b). In addition, Bowles and Demiate (2006) and Jackson et al. (2001) showed that approximately $1 / 3$ of the isoflavones present in the soybean remains in the okara,

${ }^{1}$ Fruit and Vegetable Technology Center, Food Technology Institute - ITAL, CP 139, CEP 13070-178, Campinas, SP, Brazil, e-mail: reginagrizotto@apta.sp.gov.br ${ }^{*}$ Corresponding author 
suggesting that it is a good, low cost source of nutrients for human nutrition.

In addition to the nutritional aspect, the knowledge of the technological functional properties of the dehydrated okara is essential, in order to evaluate its applications as a food ingredient. The term "technological functional property", when applied to a food ingredient, can be defined as all non-nutritional properties that influence the production and quality of a determined food. Most of the functional properties influence the sensory character of the food, mainly the texture, but they can also have important roles in the physical behavior of foods (CHEFTEL; CUQ; LORIENT, 1989).

The pneumatic flash dryer basically consists of a long tube with a variable length of up to $20 \mathrm{~m}$, depending on the evaporative capacity (PERRY et al., 1963). The material to be dried is transported through the tube by a current of hot air at high speed, impelled by potent fans. The pneumatic dryer is indicated for granular materials that fluctuate when dispersed in air current, such that they do not agglomerate or stick to the transporter walls. Coarse materials with high moisture contents should be ground in a hammer mill before drying, and it is possible to re-circulate dried material by mixing it with still moist material, dispersing the resulting mixture in a disintegrator before entering the dryer. However, literature on drying, using pneumatic flash dryer, is scarce and there are few pilot scale devices available for tests - the only paper available is a study of the flash drying of cassava flour by Brunelo and Hufenuessler (1990), carried out at the Polytechnic College of USP, São Paulo, Brazil.

The general objective of the present study was to establish the following conditions for drying okara in a pneumatic flash dryer: drying air temperature $\left(\mathrm{T}^{\circ} \mathrm{C}\right)$ and the recirculation rate of the dry residue (RR \%), using response surface methodology based on the physicochemical composition and the technological functional properties of the dehydrated okara.

\section{Materials and methods}

\subsection{Raw material}

Three hundred eighty kilograms of the residue from soymilk production known as okara, with $82.87 \mathrm{~g} .100 \mathrm{~g} \mathrm{~g}^{-1}$ moisture content, were provided by a Brazilian factory located in São Paulo, Brazil. This industrial unit was chosen from a total of nine factories based on the criterion of its location, in the Southeast of Brazil. Considering that this factory used the most adequate cultivar for the region where it was located, the cultivar had the greatest agricultural diffusion adapted to the Southeast and part of the Center-West regions of the country. The okara was transported to the Institute of Food Technology, ITAL, in Campinas, Brazil in double plastic bags, and it was stored in cold chambers with air circulation at $10^{\circ} \mathrm{C}$ until processing.

\subsection{Physical-chemical determinations}

The following determinations were carried out in both the original okara and the one dehydrated in the flash dryer: crude protein content (ASSOCIATION...,
2005), lipid content by the Bligh-Dyer method (CECHI, 1999), moisture content (ASSOCIATION..., 2005), fiber in neutral detergent (FDN) (AMERICAN..., 2003), ash content (ASSOCIATION..., 2005) and carbohydrates - calculated by difference [100 - (moisture+protein+lipid $+a s h+f d n)]$.

The determinations were performed in triplicate and the results expressed in dry weight basis (dwb) or wet weight basis (wwb).

\subsection{Technological functional properties}

The technological functional properties evaluated in the original okara and in the one dehydrated in the flash dryer were: Protein Solubility (PS), Water Holding Capacity (WHC), Emulsifying Capacity (EC) and Emulsion Stability (ES), as described below.

Protein Solubility (PS) was evaluated at $\mathrm{pH} \mathrm{3,5}$ and 7 in a saline solution $(0.1 \mathrm{M} \mathrm{NaCl})$, with the $\mathrm{pH}$ adjusted using $0.1 \mathrm{~N} \mathrm{NaOH}$ or $0.1 \mathrm{~N} \mathrm{HCl}$ (MORR et al., 1985). The suspensions were stirred for one hour at room temperature, and after centrifugation, the soluble protein contents of the supernatants were determined by the micro Kjeldahl method (ASSOCIATION..., 2005). The percentage of soluble protein was calculated using Equation 1:

$$
P S=\frac{\text { protein concentration in supernatant }\left(\mathrm{mg} \cdot \mathrm{mL}^{-1}\right) \times 50 \times 100}{\text { weight sample }(\mathrm{mg}) \times \frac{\text { protein content of sample }(\%)}{100}}
$$

Water Holding Capacity (WHC) was determined according to Regenstein, Gorimar and Sherlon (1979). The $\mathrm{pH}$ values of the suspensions were adjusted to $\mathrm{pH} 3,5$ or 7 with $0.1 \mathrm{~N}$ to $1.0 \mathrm{~N} \mathrm{NaOH}$ or $\mathrm{HCl}$, and the final volumes adjusted to result in $1 \%$ protein dispersions. After stirring for 1 hour at room temperature, $20 \mathrm{~mL}$ aliquots were centrifuged at $30,000 \mathrm{G}$ for 15 minutes at $5{ }^{\circ} \mathrm{C}$. The supernatant of each sample was reserved and the moisture (ASSOCIATION..., 2005) and protein (ASSOCIATION..., 2005) contents of the precipitates were determined. The water holding capacity was calculated using Equation 2 and it was expressed in grams of water per gram of protein ( $\mathrm{g} \mathrm{H}_{2} \mathrm{O}^{-1}$ protein):

$$
\text { WHC }=\frac{\text { hydrated weight }- \text { original weight }}{\text { sample weight }}
$$

Emulsifying Capacity (EC) was determined according to De Kanterewicz et al. (1987) with some adaptations. It was defined as the maximum amount of oil that could be dispersed in $100 \mathrm{~mL}$ of the protein dispersion prepared with "okara" flour with a particle size below $180 \mu \mathrm{m}$ ( 80 mesh sieve), prepared in distilled water and containing approximately $1 \%$ of protein. Vegetable oil was added to the dispersion at a rate of $1 \mathrm{~mL}$ oil per minute, until the point when the emulsion collapsed, visualized by change in color and phase separation. The emulsion was prepared in a Turratec homogenizer (Ultra Turrax T-25, TECNAL, Brazil) at $18,800 \mathrm{rpm}$, maintaining the temperature at about 4 to $5{ }^{\circ} \mathrm{C}$ in ice bath. The dispersion/oil proportion immediately prior to the point of collapse was considered in the calculation of the EC. The emulsifying capacity was defined as the volume $(\mathrm{mL})$ 
of oil added before reaching the inversion point, per gram of protein, according to Equation 3:

$$
E C=\frac{\text { volume of oil }\left(\mathrm{mL} .100 \mathrm{~mL} \mathrm{~L}^{-1} \text { dispersion }\right)}{\text { protein concentration of sample }\left(\mathrm{g} .100 \mathrm{mL^{-1 }} \text { dispersion }\right)}
$$

Emulsion Stability (ES) was determined according to Acton and Safle (1970), with some adaptations according to the conditions of the laboratory used. The stable emulsion obtained with the protein dispersion plus oil, according to the procedure described above for EC, was maintained for 24 hours at room temperature $\left(22 \pm 2{ }^{\circ} \mathrm{C}\right)$. Five milliliter aliquots were removed for the moisture determinations from both the freshly prepared emulsion and the emulsion after 24 hours. ES was calculated using Equation 4:

$$
E S=\frac{100-M^{24 h}}{100-M^{\text {original }}} \times 100
$$

where:

$$
\begin{aligned}
& \mathrm{ES}=\text { emulsion stability } \\
& \mathrm{M}^{24 \mathrm{~h}}=\text { moisture after } 24 \text { hours } \\
& \mathrm{M}^{\text {original }}=\text { moisture of the freshly prepared emulsion }
\end{aligned}
$$

The determinations were carried out in triplicate and the results expressed in a wet weight basis (wwb).

\subsection{Drying of the okara in the flash dryer}

The pneumatic flash dryer used in these trials was manufactured by Volpi Metallurgical Company, Jaraguá do Sul, Brazil, and it is currently at the Food Technology Institute (ITAL) in Campinas, Brazil. The drying body of the flash dryer is $3 \mathrm{~m}$ long and the internal diameter $0.15 \mathrm{~m}$, with an evaporative capacity of approximately $70 \mathrm{~kg}$ of water per hour. The air was impelled by a centrifugal fan at $1,200 \mathrm{~m}^{3} \mathrm{~h}^{-1}$ driven by a $5 \mathrm{HP}$ electric pump at $1,750 \mathrm{rpm}$. The drying air heating unit consisted of a steam system with a nominal capacity of $38,400 \mathrm{kcal} / \mathrm{h}$, enough to heat the air to $150^{\circ} \mathrm{C}$, plus an electrical resistance system with a nominal capacity of $46,000 \mathrm{kcal} / \mathrm{h}$ - the two systems installed in parallel, but operating independently. This heating unit allowed for the possibility of working in a wide range of air temperatures in automatic mode. A detailed description of this type of dryer and its functioning can be found in Perry et al. (1963).

Figure 1 shows the steps used in the drying of the okara in the flash dryer, including the stage of mixing the moist okara (83 g. $100 \mathrm{~g} \mathrm{~g}^{-1}$ moisture content) with the "seed" in proportions from 26 to $74 \%$, according to the Central Compound Rotational Design (CCRD), sufficient to achieve initial moisture levels between 26 and $61 \mathrm{~g} .100 \mathrm{~g} \mathrm{~g}^{-1}$, so as to establish the conditions to start functioning the flash dryer.

The "seed" or original okara, with $5 \mathrm{~g} .100 \mathrm{~g}^{-1}$ moisture, was produced by drying the okara in a tray drier $\left(65^{\circ} \mathrm{C} / 8 \mathrm{~h}\right)$ to a moisture content of $5 \mathrm{~g} .100 \mathrm{~g}^{-1}$, followed by grinding it in a model 740646 hammer mill (Treu \& Cia Ltda., Rio de Janeiro, Brazil) with a $1 / 2$ inch sieve, in order to reduce the particle size. Batches of approximately $5 \mathrm{~kg}$ of the moist okara and "seed" mixture were used in the eleven drying trials of the CCRD.

In all trials, the levels of moisture in the initial mixture and in the samples removed at regular intervals during the drying process were determined, until final moisture content between 3 and $5 \mathrm{~g} .100 \mathrm{~g}^{-1}$ was reached - this value being considered ideal in this case. The total drying time taken to reach the final moisture content was also noted.

In the continuous functioning regime, part of the dried residue returned through a recirculation valve to be reincorporated to the moist residue, allowing for continuous drying. The other part of the dried residue was collected for packaging. This procedure assured that the material entering the flash dryer had the moisture content required for the good functioning of the equipment. It should be noted that, for the initial start of the flash dryer, the "seed" could be substituted by some commercial flour such as manioc flour, for example.

\subsection{Statistical design}

A Central Compound Rotational Design (CCRD) was used, consisting of a $2^{2}$ factorial design for 2 independent variables at 2 levels, a star design with four axial points at a distance of $\sqrt{2}$ from the central point and three repetitions at the central point (BARROS NETO; SCARMINIO; BRUNS, 2002). Table 1 shows the lower $(-1)$ and upper $(+1)$ levels fixed for each of the two

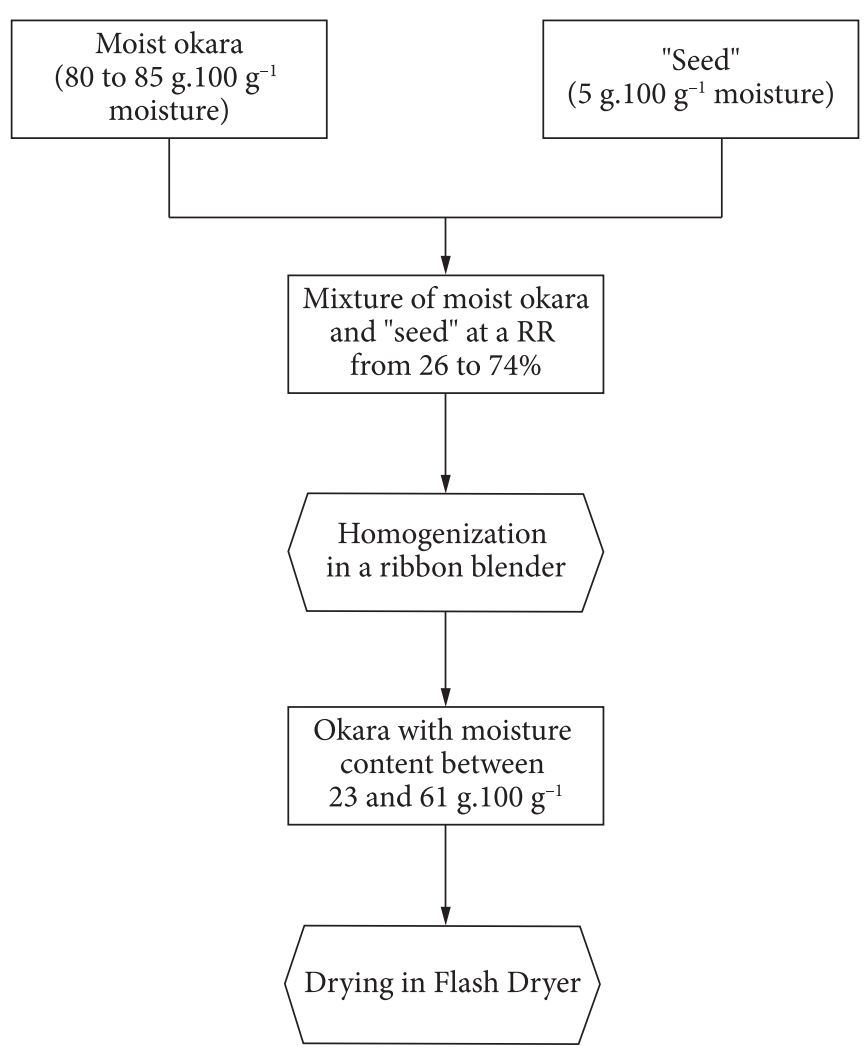

Figure 1. Basic flow diagram of the flash drying of okara, including the steps of mixing the moist okara with the "seed" at recirculation rates (RR) between 26 and 74\%, according to the CCRD. 
Table 1. Independent variables and levels of variation used in the statistical central compound rotational design.

\begin{tabular}{|c|c|c|c|c|c|c|}
\hline \multirow[t]{2}{*}{ Variables } & \multirow[t]{2}{*}{ Code } & \multicolumn{5}{|c|}{ Levels } \\
\hline & & $-\sqrt{2}$ & -1 & 0 & +1 & $+\sqrt{2}$ \\
\hline Recirculation rate of the dried material (RR in \%) & $\mathrm{x}_{1}$ & 26 & 35 & 50 & 65 & 74 \\
\hline Drying air temperature $\left(\mathrm{T}^{\circ} \mathrm{C}\right)$ & $\mathrm{x}_{2}$ & 252 & 260 & 280 & 300 & 308 \\
\hline
\end{tabular}

independent variables studied: rate of recirculation of the dried material ( $\mathrm{RR}$ in \%) and temperature of the drying air $\left(\mathrm{T}\right.$ in $\left.{ }^{\circ} \mathrm{C}\right)$, codified respectively as $\mathrm{x}_{1}$ and $\mathrm{x}_{2}$, and also the lower $(-\sqrt{2})$ and upper $(+\sqrt{2})$ levels of the axial points for the same variables.

The responses or dependent variables studied were: initial moisture, final moisture after 120 seconds, protein, lipids, fiber, ash, carbohydrates, emulsifying capacity (EC), emulsion stability (ES), protein solubility (PS) and water holding capacity (WHC) in the eleven trials resulted from the CCRD, as shown in Tables 2 and 4.

\subsection{Statistical analysis}

The results of the physicochemical determinations and the technological functional properties obtained in the eleven trials corresponding to the proposed statistical design were used to fit the quadratic model and to calculate the experimental error according to response surface methodology (BARROS NETO; SCARMINIO; BRUNS, 2002), using the version 6 Statistica program. The quadratic model for the two variables can be represented as follows: (Equation 5)

$\mathrm{Y}=\beta_{0}+\beta_{1} x_{1}+\beta_{2} x_{2}+\beta_{12} x_{12}+\beta_{11}\left(x_{1}\right)^{2}+\beta_{22}\left(x_{2}\right)^{2}+\varepsilon$

where:

$x_{1}$ and $x_{2}$ are the coded variables, $\beta_{0}, \beta_{1}, \beta_{2}, \beta_{12}, \beta_{11}$ and $\beta_{22}$ are the parameters of the regression model, and $\varepsilon$ is the experimental error.

These results were submitted to analysis of variance and to Tukey's test.

\section{Results and discussion}

\subsection{Okara composition}

Table 2 shows the physicochemical composition of the eleven residues dehydrated in the flash dryer according to the CCRD. The original okara (trial 12) was dehydrated in a tray dryer $\left(65^{\circ} \mathrm{C} / 8\right.$ hours $)$ to $5 \mathrm{~g} .100 \mathrm{~g}^{-1}$ moisture content, and the results are also presented in Table 2 to aid comprehension. The original okara, also named "seed", was used in proportions ranging from $26 \%$ to $74 \%$ according the CCRD, in mixtures with the moist okara ( $82.87 \mathrm{~g} .100 \mathrm{~g}^{-1}$ moisture content) to obtain materials with different moisture levels. The main objective was to verify the adequate initial okara moisture level for the functioning of the flash dryer.

The initial moisture contents of the residues in the eleven CCRD trials varied significantly ( $\mathrm{p} \leq 0.05$ ) - from 21 to $60 \mathrm{~g} .100 \mathrm{~g}^{-1}$, significantly influencing the total drying time required to obtain dehydrated okara with a final moisture content between 3 and 5 g. $100 \mathrm{~g}^{-1}$ - value considered ideal in this work.

The trials including smaller proportions of tray dried okara $\mathrm{RR}=26 \%$ (trial 5) and $\mathrm{RR}=33 \%$ (trials 1 and 3 ) resulted in mixtures with higher initial moisture contents, 53 to $60 \mathrm{~g} .100 \mathrm{~g}^{-1}$ (wwb), requiring from 5 to 6 minutes of drying to reach 3 to $5 \mathrm{~g} .100 \mathrm{~g}^{-1}$ (wwb) final moisture content. The mixtures with equal proportions of moist and dry okara, $\mathrm{RR}=50 \%$ (trials 7 and 11) presented moisture contents between 33 and $41 \mathrm{~g} .100 \mathrm{~g}^{-1}$ (wwb) and drying times of about 3 minutes to reach the desired moisture content. The trials with greater proportions of dry okara, $\mathrm{RR}=67 \%$ (trials 2 and 4 ) and $\mathrm{RR}=74 \%$ (trial 6) presented lower initial moisture contents (26 and $21 \mathrm{~g} .100 \mathrm{~g}^{-1} \mathrm{dwb}$ ) and dried in less than 2.5 minutes. Thus, it was concluded that it is possible to dry residues with initial moisture contents between

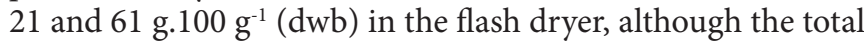
drying time can varry as a function of the initial moisture content of the residues.

The final moisture of the okara after 120 seconds was optimized through response surface methodology based on the following drying parameters: recirculation rate of the dry residue $(R R)$ and drying air temperature $(T)$. This period of time was selected because it was possible to determine the moisture content in all trials of the CCRD. The analysis of variance of the results for final moisture content after 120 seconds of drying indicated that the quadratic model fitted the experimental data (Table 3). The $\mathrm{F}$ tests for the regression $(R)$ and lack of fit $(l f)$ indicated that the regression was significant $\left(M Q_{R} /\right.$ $\left.M Q_{r}=13.14>F_{(5,5)}=5.05\right)$ and the quadratic model did not present a lack of fit $\left(Q M_{l f} / M Q_{p e}=1.21<F_{(3,2)}=9.28\right)$ at the $95 \%$ probability level. In addition, the percentage of variation explained by the model was $92.92 \%$. The analysis of the effects indicated the significant terms: mean and $\mathrm{x}_{1}$. The terms $\mathrm{x}_{2}$ and the interaction $x_{1} . x_{2}$ were non-significant at the $95 \%$ probability level, and the simplified mathematical equation could be represented by Equation 6, which satisfactorily described the response surfaces shown in Figure 2.

$\hat{y}=\underset{ \pm 1.653}{7.072-7.924} \underset{ \pm 1.010}{7} x_{1}$

According to Equation 6, one can dehydrate okara in a flash dryer to $6 \mathrm{~g} .100 \mathrm{~g}^{-1}$ of moisture content $(\hat{y}=6)$ using the $\mathrm{x}_{1}=0.135$ condition, which corresponds to $\mathrm{RR}=51 \%$ in a drying time of 120 seconds, regardless of the drying air temperature, that is, within the $252^{\circ} \mathrm{C}$ to $308^{\circ} \mathrm{C}$ range studied in this work. The RR value equals to $51 \%$ could be extrapolated to the value of $40 \mathrm{~g} .100 \mathrm{~g}^{-1}$ initial moisture content of okara, calculated by the interpolation between the values of 33 and $67 \%$ of the RR and 


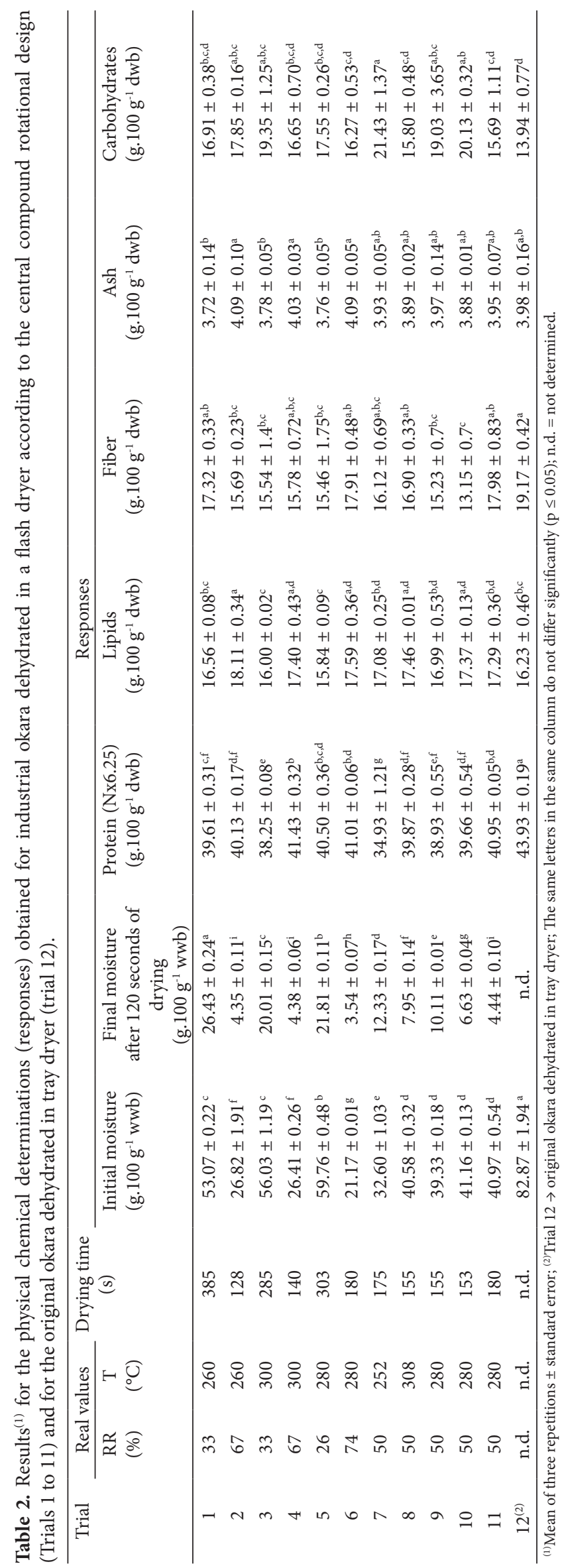


Table 3. Analysis of variance for the fit of the quadratic model to the data from the results for the moisture content of the residue after 120 seconds in the flash dryer, according to the CCRD.

\begin{tabular}{lrrrr}
\hline \multicolumn{1}{c}{ Factor } & SS & df & MS & F \\
\hline Regression (R) & 607.5497 & 5 & 121.5099 & $13,1430^{*}$ \\
Residues (r) & 46.2262 & 5 & 9.2452 & - \\
Lack of fit & 29.8680 & 3 & 9.9560 & 1,2143 \\
Pure error & 16.3982 & 2 & 8.1991 & - \\
Total & 653.8159 & 10 & - & - \\
\hline
\end{tabular}

$\%$ of the variation explained: $92.92 \%$; ${ }^{*}$ significant at $95 \%$ probability

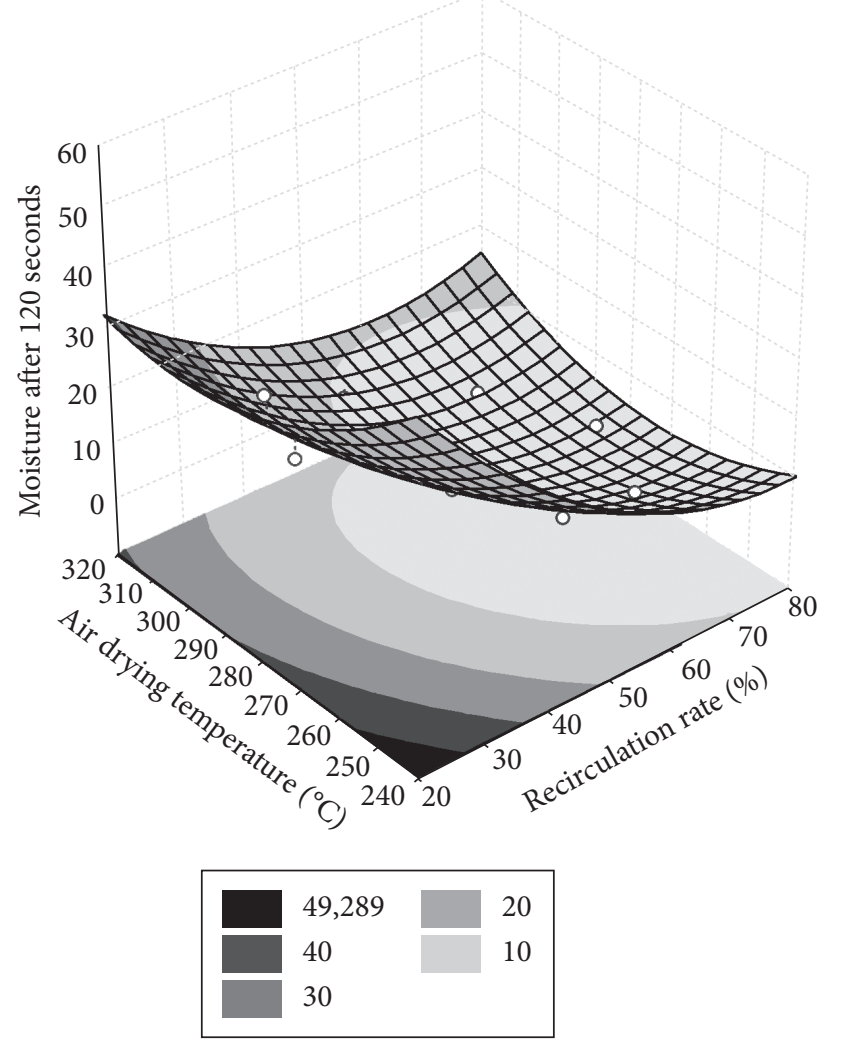

Figure 2. Response surface of the quadratic model for the response residue moisture after 120 seconds drying (y) as a function of the recirculation rate of the dried residue $\left(\mathrm{x}_{1}\right)$ versus the air drying temperature $\left(\mathrm{x}_{2}\right)$.

the respective average values of $54.5 \mathrm{~g} .100 \mathrm{~g}^{-1}$ and $26 \mathrm{~g} .100 \mathrm{~g}^{-1}$ of the initial moisture of the okara, extracted from Table 2. In other words, it is possible to obtain dried okara with $6 \mathrm{~g} .100 \mathrm{~g}^{-1}$ moisture from the okara with $40 \mathrm{~g} .100 \mathrm{~g}^{-1}$ moisture at $252{ }^{\circ} \mathrm{C}$ to $308{ }^{\circ} \mathrm{C}$ drying air temperatures. This results are supported by Tadano and co-workers (1981) cited by O’Toole (1999), who used a similar drying system to dry okara, containing initially $84.5 \%$ moisture and hot air $\left(208-254^{\circ} \mathrm{C}\right)$.

The protein content of the original okara (43.93 g.100 g-1 $\mathrm{dwb})$ differed significantly $(\mathrm{p} \leq 0.05)$ from the values obtained at the 11 trials, which ranged from 34.93 to $41.01 \mathrm{~g} .100 \mathrm{~g}^{-1} \mathrm{dwb}$. The analysis of variance showed evidence of a lack of fit for the quadratic model $\left(\mathrm{QM}_{\text {lack of fit }} / \mathrm{QM}_{\text {pure error }}=9.62>3.41=\mathrm{F}_{3,13}\right)$ at a $95 \%$ level of significance. However, all the linear $\left(\mathrm{x}_{1}, \mathrm{x}_{2}\right)$ and quadratic $\left(x_{1}^{2}, x_{2}^{2}\right)$ effects and the interaction $\left(\mathrm{x}_{1} \cdot \mathrm{x}_{2}\right)$ between the variables were significant $(\mathrm{p} \leq 0.05)$. This indicated that the protein content varied as a function of the drying parameters: recirculation rate of the dried material, $x_{1}$, and drying air temperature, $\mathrm{x}_{2}$, but in such a complicated way that it could not be explained by the mathematical model. The significant coefficients and respective standard errors of the regression parameters are showed in Equation 7.

$$
y=\underset{ \pm 0.2110}{39.851+\underset{ \pm 0.129}{0.552}} x_{1}+\underset{ \pm 0,152}{0,640} x_{1}^{2}+\underset{ \pm 0,129}{0,866} x_{2}-\underset{ \pm 0,153}{1,025} x_{2}^{2}+\underset{ \pm 0,182}{0,664} x_{1} x_{2}
$$

Observing the pairs: trials 1 and 2, and trials 3 and 4 on Table 2, where the RR changes from low (-1) to high (+1) level, at constant air drying temperature, a tendency to increase the protein content was observed, respectively, 39.61 to 40.13 g. $100 \mathrm{~g} \mathrm{~g}^{-1}$ and 38.25 to $41.43 \mathrm{~g} .100 \mathrm{~g} \mathrm{~g}^{-1}$. Moreover, when observing the pairs: trials 1 and 3 , and trials 2 and 4 , where the air drying temperature changes from low (-1) to high (+1) level, at constant RR, the same tendency could be seen. The results of these observations confirm the complexity of the mathematical model with several significant effects on the protein content.

The contents of the other components, lipid (15.84 to

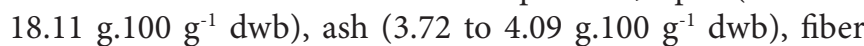
( 13.15 to 17.98 g. $100 \mathrm{~g}^{-1} \mathrm{dwb}$ ) and carbohydrates (15.69 to $21.43 \mathrm{~g} .100 \mathrm{~g}^{-1} \mathrm{dwb}$ ), obtained for the eleven residues dehydrated in the flash dryer according to the CCRD, were similar to those of the original okara (trial 12) and in agreement with values for residues from the soybean cultivars IAC 18, BRS 267 and BRS 232 studied by Grizotto et al. (2006). The analyses of variance for the values obtained for the lipid, fiber, ash and carbohydrate contents of the dried residues from the CCRD, indicated nonsignificant regression for the responses, with evidence of a lack of fit for the quadratic model. In addition, all the linear $\left(\mathrm{x}_{1}, \mathrm{x}_{2}\right)$ and quadratic $\left(x_{1}^{2}, x_{2}^{2}\right)$ effects, and the effects of the interaction $\left(x_{1} \cdot x_{2}\right)$ between the variables of these responses were not significant ( $\mathrm{p} \leq 0.05)$. Based on these results, it can be affirmed that the physicochemical composition, except to protein, of the okara dehydrated in the flash dryer did not vary as a function of the drying parameters and remained similar to the mean values observed in the original residue (trial 12).

\subsection{Technological functional properties}

Table 4 shows the results for the technological functional properties of the products obtained in the 11 trials of the CCRD 


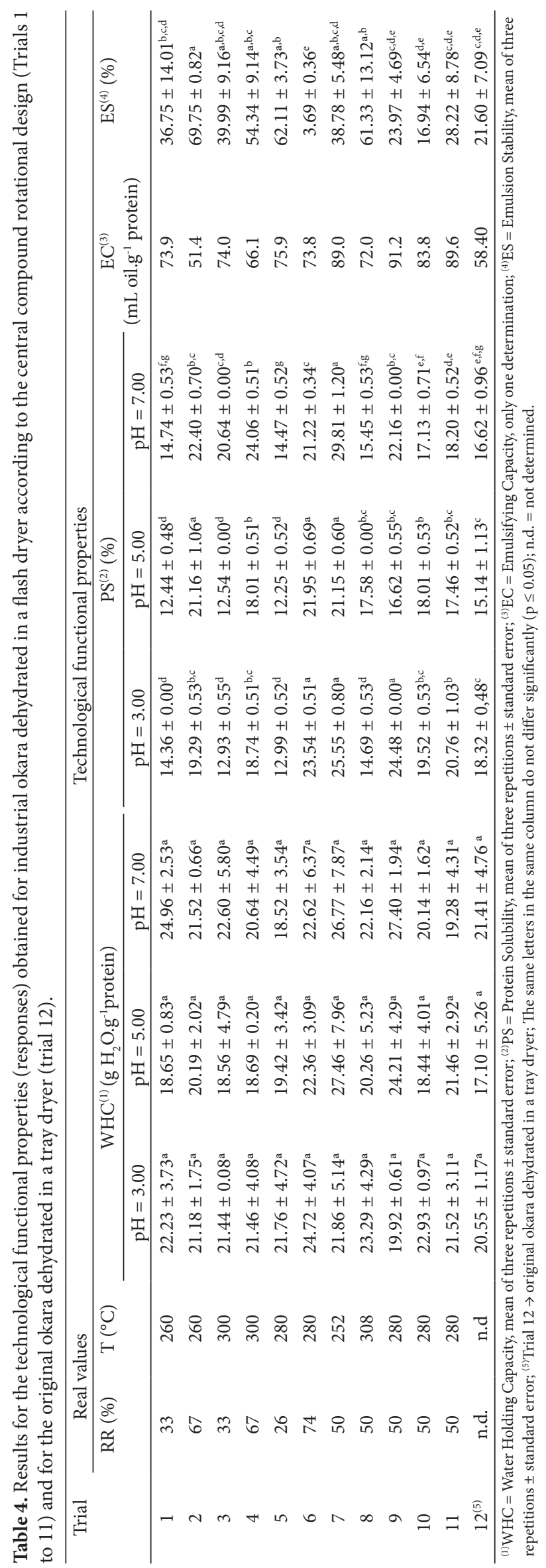


(Trials 1 to 11 ) and of the original okara (Trial 12), dehydrated in a tray dryer.

The Tukey's test for the results of the Water Holding Capacity (WHC) of the residues dehydrated in the flash dryer showed non-significant variation ( $\mathrm{p} \leq 0.05$ ): from 18.5 to $27 \mathrm{~g} \mathrm{H}_{2} \mathrm{O} . \mathrm{g}^{-1}$ protein at the $\mathrm{pH}$ values of 3, 5 and 7. Trials 7 and 9 showed the highest values for WHC, above $27 \mathrm{~g} \mathrm{H}_{2} \mathrm{O} . \mathrm{g}^{-1}$ protein, at the $\mathrm{pH}$ values of 5 and 7 . The original dehydrated okara (trial 12) showed a WHC between 17 and $21 \mathrm{~g} \mathrm{H}_{2} \mathrm{O} \mathrm{g}^{-1}$ protein in the same $\mathrm{pH}$ range, within the same variation obtained for the residues dehydrated in the flash dryer, but well above the values

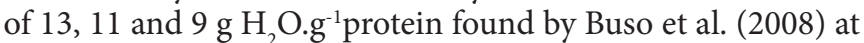
the same $\mathrm{pH}$ values for commercial texturized soybean protein. The ANOVA for the WHC results at these $\mathrm{pH}$ values showed no lack of fit for the quadratic model, but no significant linear or quadratic term. In other words, the WHC is not affected by drying conditions, both in a pneumatic flash dryer with high performance ( 3 to 6 minutes at 252 to $308^{\circ} \mathrm{C}$ ) as well as in a tray dryer for long time (8 hours) and low temperature $\left(65^{\circ} \mathrm{C}\right)$. The variation in the soluble protein contents (PS) of the residues dried in the flash dryer (trials 1 to 11 ) was from 13 to $30 \%$ at the $\mathrm{pH}$ values of 3, 5 and 7, and it was significant at the $95 \%$ probability level. The ANOVA for the PS results at $\mathrm{pH}$ values of 3, 5 and 7, indicated some influence of the variables RR and air drying temperature with significant linear and quadratic terms for each of the responses. However, no mathematical model could be established for protein solubility, since evidence of a lack of fit was found at all the studied $\mathrm{pH}$ values. The highest value for soluble protein of $29.81 \%$ was found in trial 7 at $\mathrm{pH} 7$, significantly $(\mathrm{p} \leq 0.05)$ above the value obtained for the original okara $(16.62 \%)$ at the same $\mathrm{pH}$. On the other hand, the protein level of trial 7 ( 34.9 g. $\left.100 \mathrm{~g}^{-1}\right)$ was significantly $(\mathrm{p} \leq 0.05)$ below compared to the original okara (43.9 g. $100 \mathrm{~g}^{-1}$ ), but comparable to that found by Ma et al. (1999) in commercial soy protein isolate (Supro 610 ) with less than $80 \%$ protein. This suggests that the primary structure of protein in okara was unfolded by heat during flash drying to a more soluble form, according to Wolf and Cowan (1975), and this resulted in an improved quality of the protein in the okara when evaluated for its solubility. The emulsifying capacity (EC) and emulsion stability (ES) express the emulsifying properties of the protein present in the okara. The best material is the one that shows high emulsifying capacity with good emulsion stability. One property isolated from the other does not result in good material.

The analysis of variance of the ES results indicated some influence of the air drying temperature with significant linear term. In fact, according Voutsinas, Cheung and Nakai (1983), the heat treatment seemed to impair the emulsifying capacity and stability of proteins. The $F$ test indicated evidence of a lack of fit $\left(\mathrm{QM}_{\text {lack of fit }} / \mathrm{QM} \mathrm{pure} \mathrm{error}_{\text {in }}=25.397>3.41=\mathrm{F}_{3,13}\right)$ for the quadratic model at a $95 \%$ level of significance, and no mathematical model could be established. The Emulsifying Capacity (EC) was carried out in single duplicate and, therefore, the results could not be submitted to analysis of variance.

The material obtained from trial 5 showed the capacity to produce emulsion (EC $=75.9 \mathrm{~mL}$ oil.g ${ }^{-1}$ protein $)$ with good stability $(\mathrm{ES}=62 \%)$. This material (trial 5$)$, which showed a high protein level (40.41 g. $100 \mathrm{~g}^{-1} \mathrm{dwb}$ ) with low soluble protein content (12 to $14 \%$ ) and intermediate lipid content $\left(16 \mathrm{~g} .100 \mathrm{~g}^{-1}\right.$ $\mathrm{dwb})$, was dehydrated using the lowest recirculation rate of the dried residue $(\mathrm{RR}=26 \%)$ and intermediate drying air temperature $\left(\mathrm{T}=280{ }^{\circ} \mathrm{C}\right)$. Under this condition, the desired moisture content ( $\left.6 \mathrm{~g} .100 \mathrm{~g}^{-1} \mathrm{wwb}\right)$ was reached in 303 seconds. The good performance of the technological functional properties EC and ES made the material obtained from trial 5 interesting for the production of stuffed meat products such as frankfurters, since those technological functional properties are of special importance in this class of product. The product obtained from trial 8 also showed potential for the production of such stuffed meat products. That residue showed a protein content of about $39 \mathrm{~g} .100 \mathrm{~g}^{-1}$ (dwb), a high value for EC (72 mL oil.g ${ }^{-1}$ protein) and good stability (61\%) and water holding capacity $\left(22 \mathrm{gH}_{2} \mathrm{O} .100 \mathrm{~g}^{-1}\right)$, in spite of its low soluble protein content ( 15 to $17 \%$ ) at the $\mathrm{pH}$ values of 3 , 5 and 7. The okara from trial $7\left(\mathrm{RR}=50 \%, \mathrm{~T}_{\text {drying air }}=252{ }^{\circ} \mathrm{C}\right)$ dried in 175 seconds and presented an intermediate protein content of $35 \mathrm{~g} .100 \mathrm{~g}^{-1}$ (dwb), but it was the product that showed the best results for WHC of $27 \mathrm{~g} \mathrm{H}_{2} \mathrm{O}_{\mathrm{g}} \mathrm{g}^{-1}$ protein at $\mathrm{pH}$ values of 5 and 7, and a higher PS value of $30 \%$ at $\mathrm{pH} 7$. This material presented good EC ( $89 \mathrm{~mL}$ oil.g-1 protein), but low stability (39\%). Thus, the material obtained from trial 7 could be indicated for the formulation of products where the water holding capacity is the most important characteristic, for instance, in confectionary products. The findings from trial 7 were in agreement with Ma et al. (1999), who considered that the emulsification of protein is influenced by solubility and surface hydrophobicity, and the higher emulsion stability in the okara protein isolates may be due to the higher solubility of the protein. Contradictorily, the results from trials 5 and 8, with high EC but low PS value, are the opposite of the relationship between the emulsifying properties of the proteins and its solubility, as established by Ma et al. (1999). The okara dehydrated in the tray dryer (Trial 12) showed WHC and PS results within the range of variation observed for the eleven trials of the CCRD. All the same, the values obtained for the Capacities to Emulsify (EC) and Stabilize Emulsions (ES) were below the levels obtained in the materials from trials 1 and 3, whose materials only contained $33 \%$ of okara dehydrated in a tray dryer. Therefore, one could conclude that drying okara in a tray dryer $\left(65^{\circ} \mathrm{C} / 8 \mathrm{~h}\right)$ harmed the quality of the protein regarding its capacity to produce stable emulsions. This damage was minimized when the RR of the dry residue was equal or smaller than $50 \%$.

\section{Conclusions}

Based on the results obtained, it was concluded that it is technically feasible to dry soymilk residue in a flash dryer. It is possible to dehydrate residues with initial moisture contents between 21 and $61 \mathrm{~g} .100 \mathrm{~g}^{-1}$, although the higher the initial moisture content of the residue, the longer the drying time.

The proximate concentration of the okara was not altered by the drying parameters used in this work, considering that the protein ( 36.36 to $41.39 \mathrm{~g} .100 \mathrm{~g}^{-1} \mathrm{dwb}$ ), lipid (13.19 to

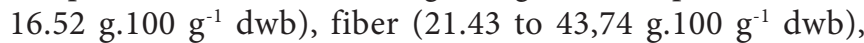
ash (3.61 to $4.59 \mathrm{~g} .100 \mathrm{~g}^{-1} \mathrm{dwb}$ ) and carbohydrate (38.91 to $45.01 \mathrm{~g} .100 \mathrm{~g}^{-1} \mathrm{dwb}$ ) contents of the products obtained from the 
eleven trials of the CCRD were similar to those found in the original residue dried in a tray dryer $\left(65^{\circ} \mathrm{C} / 8\right.$ hours $)$.

Response Surface Methodology (RSM) showed that, for an 120 -second drying cycle, the lower the moisture contents $(\hat{y})$ obtained in the residue, the higher the recirculation rate $\left(\mathrm{x}_{1}\right)$, regardless of the drying air temperature $\left(\mathrm{x}_{2}\right)$, as expressed by the equation $\hat{y}=7.072-7.924 x_{1}$, with $R^{2}=92.92 \%$.

The recirculation rate of the dry residue (RR), or $\mathrm{x}_{1}$ was preponderant over the air drying temperature $(\mathrm{T})$, or $\mathrm{x}_{2}$, considering that, from the analysis of variance, the terms $\mathrm{x}_{2}$ and $\mathrm{x}_{1} \cdot \mathrm{x}_{2}$ were non-significant at the $5 \%$ level of probability.

Based on the drying parameters used for the flash dryer, optimized by RSM, one can obtain residues with $6 \%$ moisture content (dwb) using the condition for $\mathrm{x}_{1}=0.135$, corresponding to a $\mathrm{RR}=51 \%$, with a drying cycle of 120 seconds and $\mathrm{T}_{\text {drying air }}=252^{\circ} \mathrm{C}$ to $308^{\circ} \mathrm{C}$.

The okara dried in flash dryer presents potential as food ingredient, and it could be indicated for the production of stuffed meat products, such as frankfurters, or confectionary products, based on its results for technological functional properties.

In general, it can be stated that the drying of okara in a tray dryer $\left(65^{\circ} \mathrm{C} / 8 \mathrm{~h}\right)$ harmed the quality of the protein with respect to its capacity to produce stable emulsions. This damage could be minimized by using a RR of the dry residue equal or smaller than $50 \%$.

\section{Acknowledgements}

RKG is grateful to FAPESP - 'Fundação de Amparo à Pesquisa do Estado de São Paulo', Brazil - for the financial support to this research.

This paper was presented at the $14^{\text {th }}$ World Congress of Food Science and Technology, Shanghai, China, October $19^{\text {th }}-23^{\text {rd }}, 2008$.

\section{References}

ACTON, J. C.; SAFLE, R. L. Stability of oil-water emulsion 1. Effects of surface tension, level of oil, viscosity and type of meat protein. Journal Food Science, v. 35, n. 9, p. 852-855, 1970. http://dx.doi. org/10.1111/j.1365-2621.1970.tb02011.x

AGUIRRE, J. M. et al. The utilization of soybean milk residue for the protein enrichment of cassava flour. Aproveitamento do resíduo do extrato protéico de soja em mistura com farinha de mandioca. Boletim do Instituto de Tecnologia de Alimentos, v. 56, p. 129-156, 1978.

AGUIRRE, J. M. et al. The drying and storage of the residue from the water extraction soymilk process. Boletim do Instituto de Tecnologia de Alimentos, v. 18, n. 2, p. 227-243, 1981.

AMERICAN ASSOCIATION OF CEREAL CHEMISTS - AACC. Approved Methods of the American Association of Cereal Chemists: including 2001, 2002, 2003 suplements. 10th ed. Saint Paul: AACC, 2003.

ASSOCIATION OF OFFICIAL AGRICULTURAL CHEMISTS AOAC. Official Methods of Analysis of AOAC International. 18th ed. Maryland:AOAC International, 2005.

BARROS NETO, B.; SCARMINIO, I. S.; BRUNS, R. E. Como fazer experimentos: Pesquisa e desenvolvimento na ciência e na indústria. 2th ed. Campinas: Editora Unicamp, 2002. 401 p.
BOWLES, S.; DEMIATE, I. M. Physicochemical characterization of the soymilk byproduct - okara. Ciência Tecnologia de Alimentos, v. 26, n. 3, p. 652-659, 2006. http://dx.doi.org/10.1590/S010120612006000300026

BRUNELO, G.; HUFENUESSLER, M. Drying of cassava flour in pilot plant flash fluidized bed and spouted bed dryers. Ciência e Tecnologia de Alimentos, v. 10, n. 2, p. 185-198, 1990.

BUSO, J. L. et al. Estudo da secagem do resíduo do extrato protéico de soja em "flash dryer" e avaliação da qualidade do resíduo desidratado. In: CONGRESSO INTERINSTITUCIONAL DE INICIAÇÃO CIENTÍFICA, 2., 2008, Campinas. Anais... Campinas: Instituto de Tecnologia de Alimentos, 2008. 1 CD ROM.

CECHI, H. M. Fundamentos teóricos e práticos em análise de alimentos. Campinas: Editora Unicamp, 1999. p. 96-97.

CHEFTEL, J. C.; CUQ, J. L.; LORIENT, D. Proteínas alimentarias: bioquímica - propriedades funcionales, valor nutricional modificaciones químicas. Zaragoza: Acribia, 1989. 346 p.

COSTA, S. I.; MORI, E. E. M. The principal uses of soybean for human consuption. Boletim do Instituto de Tecnologia de Alimentos, v. 56, n. 1, p. 27-49, 1978.

DE KANTEREWICZ, R. J. et al. Water-oil absortion index (WOAI): A simple method for predicting the emulsifying capacity of food proteins. Journal Food Science, v. 52, n. 5, p. 1381-1383, 1987. http://dx.doi.org/10.1111/j.1365-2621.1987.tb14087.x

GRIZOTTO, R. K. et al. A study of new soybean cultivars for the production of protein extract. In: SEMINÁRIO DE INICIAÇÃO CIENTÍFICA, 13., 2006, Campinas. Resumos... Campinas: Instituto de Tecnologia de Alimentos, 2006. 1 CD ROM.

HACKLER, L. R.; HAND, D. B.; VAN BUREN, J. P. A comparison of the nutritional value of protein from several soybean fractions. Journal Food Nutrition, v. 80, n. 3, p. 205-209, 1963.

JACKSON, C. J. C. et al. Effect of processing on the content and composition of isoflavones during manufacturing of soy beverage and tofu. Process Biochemistry, v. 37, n. 4, p. 1117-1123, 2001.

MA, C. Y. et al. Isolation and characterization of protein from soymilk residue (okara). Food Research International, v. 29, n. 8, p. 799-805, 1997. http://dx.doi.org/10.1016/0963-9969(95)00061-5

MORR, C. V. et al. Collaborative study to develop a standardized food protein solubility procedure. Journal Food Science, v. 50, n. 6 , p. 1715-1718, 1985. http://dx.doi.org/10.1111/j.1365-2621.1985. tb10572.x

O'TOOLE, D. K. Characteristics and use of okara, the soybean residue from soy milk production - A Review. Journal Agricultural Food Chemistry, v. 47, p. 363-371, 1999.

PERRY, J. H. et al. Chemical Engineers' Handbook. 4th ed. New York: Mc Graw Hill. 1963. p. 20-54.

REGENSTEIN, J. M.; GORIMAR, T. S.; SHERLON, J. W. Measuring the water holding capacity of natural actomyosin from chicken breast muscle in the presence of pyrophosphate and divalent cations. Journal Food Biochemistry, v. 3, n. 4, p. 205-211, 1979. http:// dx.doi.org/10.1111/j.1745-4514.1980.tb00776.x

TRAVAGLINI, D. A. et al. Pilot-plant studies on dried soymilk. Coletânea do I Instituto de Tecnologia de Alimentos, v. 11, n. 1, p. 139-152, 1980a.

TRAVAGLINI, D. A. et al. The processing of soy milk residue mixed with cron grits. Boletim do Instituto de Tecnologia de Alimentos, v. 17, n. 3, p. 275-296, 1980 b.

VOUTSINAS, L. P.; CHEUNG, E.; NAKAI, S. Relationship of hydrophobicity of emulsifying properties of heat denatured proteins. Journal Food Science, v. 48, p. 26-32, 1983. http://dx.doi. org/10.1111/j.1365-2621.1983.tb14781.x

WOLF, W. J.; COWAN, J. C. Soybean as a food source. Cleveland: CRC Press. 1975. p. 325-377. 